\title{
Authigenic calcite-dolomite series carbonates of lacustrine bottom sediments: morphology, geochemistry, and mineralogy (South of Western Siberia)
}

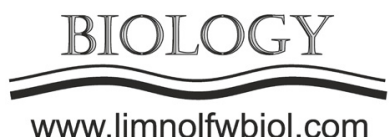

\author{
Ovdina E.A.*, Strakhovenko V.D., Solotchina E.P.
}

Sobolev Institute of Geology and Mineralogy, Siberian Branch of the Russian Academy of Sciences (IGM SB RAS), 3 Akad. Koptyug Ave., Novosibirsk, 630090, Russia

\begin{abstract}
Identifying the features of modern mineral formation is currently an urgent problem. On the example of small lakes in the South of Western Siberia, authigenic calcite-dolomite (Cal-Dol) minerals of various magnesia degrees are considered. Modern mineral formation occurs on the background of demolition of terrigenous and organic matter accumulation in the sediments. The morphology, geochemistry and mineralogy of authigenic Cal-Dol minerals are considered
\end{abstract}

Keywords: Calcite-dolomite series carbonates; authigenic minerals; Western Siberia; small lakes; bottom sediments

\section{Introduction}

The research area covers the South of Western Siberia (landscape zones of sub-taiga, forest-steppe and steppe). Along with other authigenic minerals (amorphous silica, pyrite, illite, and smectites (rarely), the formation of Cal-Dol series and aragonite carbonates has been established in small lakes. The aim is to characterize the features of geochemistry, mineralogy and morphology of authigenic Cal-Dol series minerals on the example of small lakes in the South of Western Siberia. The objects of research are 46 small (up to 10 $\mathrm{km}^{2}$ ) lakes with a depth of $3-5 \mathrm{~m}$ with a carbonate type of sediment, located in the South of Western Siberia.

Sapropels and mineral silts are the bottom sediments of the studied small lakes. Sapropels are divided into types and classes depending on the composition of the organic and mineral parts (ash content) (Strakhovenko et al., 2016). Mg-calcites and Caexcess dolomites dominate among authigenic carbonate minerals (Solotchina et al., 2015; Strakhovenko et al., 2015).

Lake waters are mostly alkaline $(\mathrm{pH}>8)$, with the exception of some sub-taiga lakes ( $\mathrm{pH}$ 6.3-6.7). The Eh indicator of all lakes is positive and high enough; the content of $\mathrm{O}_{2}$ dissolved in water in most lakes is high enough and varies from $134 \%$ (11.47 $\left.\mathrm{mg} \mathrm{L}^{-1}\right)$ to $72 \%\left(6.29 \mathrm{mg} \mathrm{L}^{-1}\right)$. The TDS of water varies significantly from fresh and brackish, found in all landscape zones, to brines in the steppe landscape. As a result of the transformation of the water chemical composition in the studied lakes due to evaporation and winter cryogeochemical processes, mainly bicarbonate waters with variations of cationic (Ca-Na-Mg) and anionic $\left(\mathrm{Cl}^{-}-\right.$ $\mathrm{SO}_{4}{ }^{2-}$ ) composition are formed.

\section{Material and methods}

Sampling of lake components (water, bottom sediments, biota, soils, and rocks of catchment areas) was done. Bottom sediments were collected from the catamaran by a cylindrical sampler with a vacuum shutter (diameter $82 \mathrm{~mm}$, length $50 \mathrm{~cm}$ ). The core samples of bottom sediments were sampled with an interval of $3-5 \mathrm{~cm}$. Physical and chemical variables were recorded in situ ( $\mathrm{pH}, \mathrm{Eh}, \mathrm{TDS})$.

Further studies of the samples chemical composition were held at the Analytical Center for multi-elemental and isotope research SB RAS, Laboratory of Geochemistry of noble and rare elements of IGM SB RAS, Novosibirsk. The lake components were studied using a set of modern analytical methods (atomic absorption spectrometry; X-ray fluorescence analysis; X-ray diffractometry (XRD); scanning electron microscopy (SEM)).

Differential diagnostics of low-temperature calcite-dolomite carbonates was performed by X-ray diffractometry (XRD). Mg- calcites in terms of $\mathrm{d}_{104}$ are divided into three groups: low- magnesian calcite with $\mathrm{MgCO}_{3}$ content in the structure $<4-5$ mol. \% (3.036> $\mathrm{d}_{104}>3.020 \AA$ A); intermediate $\mathrm{Mg}$ - calcite with $\mathrm{MgCO}_{3}$ content in the structure 5-18mol. \% (3.02> $\mathrm{d}_{104}>$ 
$2.98 \AA$ A); high-magnesian calcite with $\mathrm{MgCO}_{3}$ content in the structure $30-43 \mathrm{~mol} . \%\left(2.94>\mathrm{d}_{104}>2.91 \AA\right)$. Ca-excess dolomites, in the structure of which the excess of $\mathrm{CaCO}_{3}$ can reach 7 mol. \% relative to stoichiometric dolomite, characterized by $\mathrm{d}_{104}$ values from 2.910 to $2.887 \AA$.

\section{Results and discussion}

In our case, we can trace the entire spectrum of calcite-dolomite series carbonates formed in small lakes bottom sediments in the South of Western Siberia from low-magnesian calcite to Ca-dolomite. Variations of $\mathrm{CaO}$ and $\mathrm{MgO}$ content in Ca-dolomite are shown in the range of $10-15 \%$-eq relative to stoichiometric dolomite. The sizes of crystals are from $<5-10$ to 20$30 \mu \mathrm{m}$ and their clusters are $100-150 \mu \mathrm{m}$, which can be observed using SEM. Minerals have a low degree of crystallinity, and X-ray amorphous components are present in significant amounts on diffractograms.

Biochemogenic low- magnesian calcite, calcite and aragonite are formed in lakes with water TDS from ultra-freshwater to brine (from $<0.2$ to 400 $\mathrm{g} \mathrm{L}^{-1}$ ). Mainly, these are rhombohedral crystals up to $20-30 \mu \mathrm{m}$, dendritic aggregates (fusion of thin scalenohedral crystals), zonal-concentric formations, pseudomorphoses by mortmass.

Chemogenic intermediate and high-magnesian calcites and Ca-excess dolomites are deposited in lakes with sodium bicarbonate (soda) and sodium chloridebicarbonate composition of water with a TDS $>3 \mathrm{~g} \mathrm{~L}^{-1}$ and $\mathrm{pH}>9$. Biochemogenic high-magnesian calcites, Ca-excess dolomites are deposited in lakes with a bicarbonate-sodium (soda) water composition with a TDS $<3 \mathrm{~g} \mathrm{~L}^{-1}$ and $\mathrm{pH}>9$ as a result of changes in physical and chemical conditions due to a combination of landscape, geochemical and biogenic factors.

Individual crystals of high-magnesian calcites and Ca-excess dolomites do not exceed $10 \mu \mathrm{m}$, and very rarely form well-formed rhombohedral crystals. Usually a set of crystals $(<5 \mu \mathrm{m})$ forms a "porridge-like" mass of high-magnesian composition.

\section{Conclusions}

One of the main authigenic minerals in the small lakes bottom sediments in the South of Western Siberia are Cal-Dol carbonates. They are common in lakes of the entire salinity spectrum and have a correlation of magnesia content in carbonates with a set of landscape, geochemical and biogenic factors. Individual crystals of low-magnesian calcites are up to $20-30 \mu \mathrm{m}$ in size, while high-magnesian calcites and Ca-dolomites are $<5$ $10 \mu \mathrm{m}$. Clusters of crystals are 100-150 $\mu \mathrm{m}$, which can be observed using SEM, and they have a low degree of crystallinity. Morphology of formations: rhombohedral and scalenohedral crystals, pseudomorphoses by mortmass," porridge-like" mass.

\section{Acknowledgments}

Work is done on state assignment of IGM SB RAS with financial support of Ministry of Science and Higher Education of the Russian Federation.

\section{References}

Solotchina E.P., Sklyarov E. V., Strakhovenko V.D., Solotchin P.A., Sklyarova O.A. 2015. Mineralogy and crystal chemistry of carbonates in modern sediments of shallow lakes of Olkhon area (Baikal region). Doklady Earth Sciences 461: 394-400. DOI:10.1134/S1028334X15040157

Strakhovenko V.D., Roslyakov N.A., Syso A.I., Ermolaeva N.I., Zarubina E.Y., Taran O.P., Puzanov A. V. 2016. Hydrochemical characteristic of sapropels in Novosibirsk oblast. Water Resources 43: 539-545. DOI:10.1134/ S0097807816030167

Strakhovenko V.D., Solotchina E.P., Vosel' Y.S., Solotchin P.A. 2015. Geochemical factors for endogenic mineral formation in the bottom sediments of the Tazheran lakes (Baikal area). Russian Geology and Geophysics 56: 14371450. DOI: 10.1016/j.rgg.2015.09.006 